\title{
The paradigm of induced chemical mutagenesis of Allium sativum $\mathrm{L}$.
}

\author{
$V I$ Nemtinov $^{1}, A V$ Shirokova $^{2}, Y u N$ Kostanchuk $^{1, *}, O A$ Pekhova $^{1}, L A$ Timasheva $^{1}, I V$ \\ Belova $^{1}$, and $I L$ Danilova $^{1}$ \\ ${ }^{1}$ Research Institute of Agriculture of Crimea, 150, Kievskaya str., 295493, Simferopol, Russia \\ ${ }^{2}$ Koltsov Institute of Developmental Biology of RAS, Vavilova Street, 26, 119334, Moscow, Russia
}

\begin{abstract}
The scheme of induced chemical mutagenesis of treatment of Allium sativum L. air bulbs of winter garlic bred by FSBSI "Research Institute of Agriculture of Crimea", grown in a breeding nursery, has been developed. Two chemical mutagens of the first group, capable of transferring alkyd compounds to other plant cells were used in the study. Different concentrations of treatments and monitoring of mutagenesis made it possible to determine the behavior of Allium sativum air bulbs in dynamics: one cloves $-\mathrm{M}_{0}$ mutants (large, medium and small fractions); bulbs - cloves ( $M_{1}$ mutants of the 1st generation); bulbs - cloves $\left(M_{2}-2\right.$ nd generation mutants). The aim of this work is to assess the morphological changes of Allium sativum L., the effect of chemical mutagens, and the selection of visible mutation-altered forms with valuable economic traits for use in breeding, creating new varieties adapted in Crimea. Monitoring was carried out, the reaction of garlic treated with two chemical mutagens was assessed: DEP (diethyl phosphate) $-0.025 ; 0.05$ and $0.1 \%$, as well as DMS (dimethyl sulfate) $-0.02 ; 0.04$ and $0.08 \%$ solutions. For control, a sample of Allium sativum L. air bulbs soaked in water was taken. For 2017-2020, different concentrations of mutagens acted selectively on morphometric and economic characteristics, as well as the chemical composition of winter garlic.
\end{abstract}

\section{Introduction}

Garlic is one of the most useful products for human health with a wide range of medicinal properties, therefore, the varietal set in the Register of Breeding Achievements of Russia is annually replenished. In total, 80 varieties of winter garlic of domestic and foreign selection and 14 varieties of spring are registered in the State Register for 2019. However, due to the variety of climatic conditions of the country's territory, they cannot satisfy the arid climate of Crimea. According to Sych [1], today production urgently needs a set of 4-5 varieties. Polyakov and Zubaliy [2] advise to renew the planting stock of garlic every 3-5 years.

At the end of the twentieth century, the FAO department (IAEA [3]) consisted of more than 1300 improved, profitable mutagenic varieties of agricultural crops - cereals, fruits, vegetables (garlic, pepper, peas, etc.) and flowers. Using this, farmers in the USA, Japan,

\footnotetext{
*Corresponding author: kostanyulya@mail.ru
} 
Pakistan, China, India, Bangladesh, Germany and Slovakia also grow rice, barley, wheat, cotton, soybeans, peas and other crops. Garlic production is widely used for food and medicinal purposes (Nemtinov and Shirokova [4]). In the process of reproduction of garlic, selection towards vegetative development and productive forms occurs. Some authors believe that the industrial system of commercial use limits the selection of the species, the use of the existing genetic variability of induced mutations, i.e. methods of obtaining new forms (Zheng et al. [5]; Matijevic et al. [6]). The use of mutagens determines the assessment of biological effects affecting a specific cell or tissue and depends on the type of mutagen, the dose of treatment (or radiation, IAEA [7]), which is important for the growth and development of a plant or explant (Taner and Kunter [8]). According to Hazieva et al. [9] the state of mutants is also assessed by yield based on the concentration of doses of mutagens or the range of irradiation. For example, gamma rays are used to reduce postharvest crop losses, delay early germination, control pests and diseases, prolong the shelf life of products, etc. (Piri et al. [10]). A study of gamma radiation was carried out to increase the yield of garlic, to improve characteristics such as inhibition of germination (Taner and Kunte [8]; Perez et al. [11]), morphological changes (Wi et al. [12]). The combination of techniques such as tissue culture and mutagenesis provides a large number of options for selecting mutants free from pests and diseases (Zheng et al. [5]). Thus, using the example of radiation mutagenesis, the use of chemical mutagenesis on garlic is relevant in the creation of new forms with stable metric characteristics, better chemical properties, increased productivity, with the aim of using it in breeding practice. However, the literature sources in solving the breeding problems of Allium sativum by the method of chemical mutagenesis do not reveal the completeness of research, which is a novelty in solving the problem.

For the world market, a characteristic trend is the dynamic growth of production and consumption of meat products, as the most important factor in improving the quality of nutrition. An increase in meat consumption of about $2 \%$ per year tends to increase production to 338 million tons by 2020 . In general, by 2020, compared to 2010, an increase in meat consumption was predicted by almost 60 million tons (Ilyina [13]). Consequently, for processing meat into sausages and as spices, the demand for garlic and especially garlic powder will increase annually. Moreover, recently, due to the new discoveries of original varieties of garlic in the treatment of a number of diseases, including oncological ones, its production in the world has increased significantly (Koretsky and Kupreenko [14]). In Crimea, an increase in sheep breeding is planned by 2020, which will expand the production of lamb and the need for garlic. China is the world leader in garlic cultivation. According to Litvinova and Borisova [15], the production of garlic in this country in 2012 amounted to 20 million tons. The import of garlic to Russia is about $17-18 \%$ of the market structure, however, since in Russia garlic is grown on an industrial basis in small volumes (the main production is concentrated in households), the share of imports on the garlic product market is estimated at $90-98 \%$. There is practically no export.

The average retail prices for fresh garlic in 2020 in connection with the COVID-19 pandemic were set at 200-250 rubles per $1 \mathrm{~kg}$. It should be noted that consumer prices for garlic have experienced strong background dependence over the past 6 years. Unstable yields (associated with erroneous selection of planting material, viral diseases - yellow mosaic Lys $v$, yellow dwarfism Gys v, streak Oys $v$ and many poliviruses) are factors that influence the result of production (Kakareka and Pleshakova [16], Nalobova et al. [17]). It is necessary to improve the method of planting material recovery. Reproduction of garlic through an air bulb using chemical mutagenesis is one of the ways to achieve the goal.

The aim of this work is to study the morphological changes in Allium sativum L. from the effects of the chemical mutagens DEP and DMS, and to select visible mutationally 
modified forms with valuable economic traits for use in breeding, and create new varieties adapted in Crimea.

It has long been accepted that the distribution area of the garlic variety in climatic conditions ranges from 150-200 km. The movement of garlic varieties from one geographical area to another, differing in climate, is usually accompanied by a change in the characteristics of the variety (Nemtinov and Shirokova [4]).

In this regard, the tendency of the prevalence of low-yielding garlic populations can be overcome by conducting targeted selection. The task is to study the variability of the traits of winter garlic with the help of strong chemical mutagens DEP and DMS, to select valuable morphometric forms with the best economically valuable traits and chemical composition for use in breeding.

In connection with the presence of many viral diseases and bulb nematodes, the question of improving the planting material is acute. The following in vitro technologies for the elimination of viruses and other phyto-pathogens from plant tissues are known: meristem culture, thermotherapy, chemotherapy, cryotherapy. For in vitro isolation, Polyakov and Zubaliy [2] used immature air garlic bulbs (with the least internal infection) when cultivated on a section containing 6-benzyladenine in combination with NAA, which also contributed to the health of the planting material. In this regard, Nalobova et al. [17] consider it normal to grow one clove - a set of garlic air bulbs, since the viral infection most of all accumulates in winter garlic cloves (up to 94\%) and less in air bulbs (88\%). In this regard, in order to increase the productivity and improve the health of winter garlic, we used the method of induced chemical mutagenesis, which made it possible to eliminate the disadvantages in obtaining highly productive individuals. Their further reproduction is associated with clonal selection.

\section{Objects and methods of research}

In the fall of 2015, in collaboration with the Koltsov Institute of Developmental Biology of Russian Academy of Sciences (Moscow), air bulbs of shooting garlic of the local population (Ukromnoye village, Republic of Crimea) were treated for 16 hours with chemical mutagens of the first group, which are capable of transferring alkyd compounds to other cells - DEP (diethyl phosphate) $0.025 \%, 0.05$ and $0.1 \%$, as well as DMS (dimethyl sulfate) $0.02 \%, 0.04$ and $0.08 \%$. These mutagens easily react with protein molecules. ElNashar et al. [18] found that the largest number of visible phenotypic changes was obtained precisely under the influence of DMS and DEP, and this is confirmed by Roychowdhuri et al. [19] and Kudina [20]. In the control, air garlic bulbs were soaked in water for 16 hours.

Sowing of treated air bulbs in open ground was carried out in the department of selection and seed production of vegetables and melons of the FSBSI "Research Institute of Agriculture of Crimea" (Ukromnoye village) in the 1st decade of November 2015 according to the scheme $40+25 \times 8 \mathrm{~cm}$, that is, at the rate of 384.6 thousand pcs $/ \mathrm{ha}$. In each variant, 100 air bulbs were sown. A total of 700 pieces were sown in the experiment weighing $1000 \mathrm{pcs}$. that equal to $35 \mathrm{~g}$ for all options.

Observations and selection of modified forms were carried out during the entire growing season: seedlings, leaf formation, bulb formation, peduncle formation, harvest ripeness. Plants were analyzed according to a complex of features: height; the number of leaves, their length and width; diameter and height of the bed stem; diameter and weight of the bulb; the number of cloves and their weight; coloration of the outer scales of the bulb and leathery scales of the cloves. The chemical composition was determined by the following indicators: dry matter, total sugars, vitamin C, essential oils.

Plants were analyzed in generations in 3 replicates. Quantitative registration of mutations was taken into account in the following ways: 1) the ratio of morphometric 
indicators to control; 2) determination of the coefficient of variability of morphometric indicators to control; 3) determination of the correlation coefficient - "leaf length - bulb diameter", "leaf length - bulb mass". The statistical processing of the experimental results was carried out using the Excel package.

\section{Results and discussion}

In 2016, on the experimental field at FSBSI "RIA of Crimea", monitoring of the assessment of mutants continued, where in the 3rd decade of October mutants - one clove of garlic by fractions were sown in a row pattern every $45 \mathrm{~cm}$ into open ground. The large fraction included mutants - one clove (M large) $2.5-3 \mathrm{~cm}$ in diameter, the medium (M medium) from 1.5 to $2.5 \mathrm{~cm}$, and the small (M small) less than $1.5 \mathrm{~cm} \mathrm{[4].}$

Practitioners of vegetable growers believe that the more cloves in the bulb, the higher the likelihood of expanded reproduction of varieties of garlic. When processing air bulbs with chemical mutagens, there was a different number of cloves in the bulbs, from 2-3 to 78 pieces (table 1 ).

Table 1. Distribution of the number of garlic cloves in a large fraction bulb using chemical mutagens of various concentrations.

\begin{tabular}{|c|c|c|c|c|c|c|c|}
\hline \multirow{6}{*}{$\begin{array}{l}\text { Number of } \\
\text { cloves in } \\
\text { bulb, pcs } / \% *\end{array}$} & \multirow{2}{*}{$\begin{array}{c}\text { Control } \\
\text { without } \\
\text { treatment }\end{array}$} & \multicolumn{3}{|c|}{ DEP preparation, $\%$} & \multicolumn{3}{|c|}{ DMS preparation, $\%$} \\
\hline & & 0.025 & 0.05 & 0.1 & 0.02 & 0.04 & 0.08 \\
\hline & $4-5$ & $4-5$ & $4-5$ & $4-5$ & $4-5$ & $4-5$ & $4-5$ \\
\hline & 75 & 97 & 57 & 100 & 33 & 88 & 100 \\
\hline & $7-8$ & 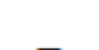 & $7-8$ & 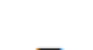 & $6-7$ & $6-7$ & - \\
\hline & 25 & - & 43 & - & 67 & 12 & - \\
\hline
\end{tabular}

Expanded reproduction of garlic depends on the number of cloves in the bulb from $6 \ldots .8$ pcs and more. In our case, the largest percentage of $43 . .67 \%$ of the cloves in the bulbs fell on the use of preparations: DEP $0.05 \%$ and DMS $0.02 \%$. The inheritance of the color of the leathery scales of the cloves was slightly violet (did not differ from the control) for the preparation $0.05 \%$ DEP and $0.02 \%$ DMS. Treatment with $0.025 \%$ DEP, $0.1 \%$ DMS, $0.04 \%$ DMS and $0.08 \%$ DMS determined the difference in the color of mutant cloves, respectively: blurred violet stripes, intensely pronounced violet stripes and intense violet coloration. The internal consistency of the cloves was white for two preparations $0.05 \%$ DEP and $0.1 \%$ DMS; in the control and in other variants it was cream. In the control, in the large fraction, $75 \%$ of the bulbs contained $4-5$ cloves, the remaining $25 \%$ contained $7-8$ pieces. Small and medium fractions of the bulbs consisted of 2-5 cloves, which were excluded from the experiment.

In the technology of growing varieties of garlic, morphometric indicators are important - plant height, arrangement of leaves in space, etc. In our example, in comparison with the control, the height of mutants increased with an increase in the concentration of both mutagens in the preparations; DEP at $6.2 \mathrm{~cm}$ and DMS at $8.7 \mathrm{~cm}$ (table 2). 
Table 2. Morphometric signs of the height and number of leaves of plants of Allium sativum L. winter garlic (2017-2019).

\begin{tabular}{|c|c|c|c|c|c|c|c|c|}
\hline \multirow{2}{*}{$\begin{array}{c}\text { Number of mutant } \\
\text { and mutagen } \\
\text { concentration (\%) }\end{array}$} & \multicolumn{3}{|c|}{ Plant height and variability } & \multicolumn{5}{c|}{$\begin{array}{c}\text { Number of leaves and their } \\
\text { variability }\end{array}$} \\
\cline { 2 - 9 } & $\mathrm{cm}$ & $\begin{array}{c} \pm \text { to } \\
\text { st, cm }\end{array}$ & $\mathrm{V}, \%$ & $\begin{array}{c} \pm \text { to } \\
\text { st, \% }\end{array}$ & $\mathrm{pcs}$ & $\begin{array}{c} \pm \text { to } \\
\text { st }\end{array}$ & $\mathrm{V}, \%$ & $\begin{array}{c} \pm \text { to st, } \\
\%\end{array}$ \\
\hline $\begin{array}{c}\text { 1.Control, st } \\
\text { (without } \\
\text { treatment) }\end{array}$ & 85.0 & 0.0 & 4.8 & 0.0 & 9.1 & 0.0 & 8.5 & 0.0 \\
\hline $2.0 .025 \mathrm{DEP}$ & 86.4 & +1.4 & 3.2 & -1.6 & 8.3 & -0.8 & 5.0 & -3.5 \\
\hline $3.0 .05 \mathrm{DEP}$ & 91.2 & +6.2 & 4.8 & 0.0 & 9.4 & +0.3 & 6.4 & -2.1 \\
\hline $4.0 .1 \mathrm{DEP}$ & 91.2 & +6.2 & 2.6 & -2.2 & 9.7 & +0.6 & 7.9 & -0.6 \\
\hline $5.0 .02 \mathrm{DMS}$ & 90.5 & +5.5 & 3.9 & -0.9 & 9.5 & +0.4 & 7.5 & -1.0 \\
\hline $6.0 .04 \mathrm{DMS}$ & 93.5 & +8.5 & 1.5 & -3.3 & 9.1 & 0.0 & 6.6 & -1.9 \\
\hline $7.0 .08 \mathrm{DMS}$ & 93.7 & +8.7 & 7.9 & +3.1 & 9.1 & 0.0 & 6.6 & -1.9 \\
\hline $\bar{x}$ & 90.2 & & & & 9.2 & & & \\
\hline $\bar{S}$ & \pm 3.9 & & & & \pm 0.4 & & & \\
\hline $\bar{x}$ & & & $4.1 \pm 3$ & & & & $6.9 \pm 1.7$ & \\
\hline $\mathrm{V} \pm \mathrm{S}_{\mathrm{v}}$ & & & .4 & & & & & \\
\hline
\end{tabular}

The results of statistical processing confirm the reliability of the average population of the height of this group of mutants in the range of $\pm 91.2 \ldots 93.7 \mathrm{~cm}$, where the concentrations of $0.05 \%$ DEP and $0.04 \ldots 0.08 \%$ DMS turned out to be more influential, since they exceeded the average $(\bar{x}=90.2)$ by $1.1 \ldots 3.5 \mathrm{~cm}$. The rest had lower values. The absolute error of the average ( $S \bar{x}=3.9 \%$ ) and variability were insignificant $(\mathrm{V}=4.1 \%)$.

The number of leaves, their location depends on the height of the plant. Treatment of air bulbs with various mutagens influenced the number of leaves and their parameters (table 2). Medium and high dosages of mutagens $0.05 \ldots 0.1 \%$ DEP and low 0.02\% DMS increased the number of leaves by $0.3 \ldots 0.6$ pcs compared to control and average $(\bar{x}=9.2)$. The absolute error of the average is equal to $S \bar{x}=0.4 \%$ with insignificant variability of the trait $(\mathrm{V}=6.9 \pm 1.7 \%)$. The effect of the chemical mutagen $0.05 \%$ DEP on garlic bulbs was the most influential in increasing the length of the leaves (table 3).

Where the increase in leaf length by $3.8 \mathrm{~cm}$ exceeded the average aggregate data for the linear size of leaves $-\bar{x}=59.5 \mathrm{~cm}$. The rest of the variants had lower values. With an absolute error of the average $S \bar{x}=1.3$, the variability in the length of leaves of mutant No. 3 was insignificant, $\mathrm{V}=4.8 \%$. Over the years of research, mutagens of different concentrations reduced the leaf width by $3 \ldots . .6 \%$ with a cumulative average $\bar{x}=3.0 \mathrm{~cm}$ and a average error $S \bar{x}=0.1$ (table 3 ). 
Table 3. Morphometric features of the length and width of plant leaves of Allium sativum L. winter garlic (2017-2019).

\begin{tabular}{|c|c|c|c|c|c|c|c|c|}
\hline \multirow{2}{*}{$\begin{array}{c}\text { Number of } \\
\text { mutant and } \\
\text { mutagen } \\
\text { concentration } \\
\text { (\%) }\end{array}$} & \multicolumn{4}{|c|}{ Leaf length and variability } & \multicolumn{4}{|c|}{ Leaf width and variability } \\
\hline & $\mathrm{cm}$ & $\begin{array}{c} \pm \text { to } \\
\text { st }\end{array}$ & $\mathrm{V}, \%$ & $\begin{array}{c} \pm \text { to st } \\
\%\end{array}$ & $\mathrm{~cm}$ & $\begin{array}{c} \pm \text { to } \\
\text { st }\end{array}$ & $\mathrm{V}, \%$ & $\begin{array}{l} \pm \text { to } \\
\text { st \% }\end{array}$ \\
\hline $\begin{array}{l}\text { 1. Control, } \\
\text { st (without } \\
\text { treatment) }\end{array}$ & 59.3 & 0.0 & 4.4 & 0.0 & 3.2 & 0.0 & 10.4 & 0.0 \\
\hline 2. $0.025 \mathrm{DEP}$ & 61.1 & +1.8 & 5.7 & +1.3 & 3.0 & -0.2 & 5.1 & -5.3 \\
\hline 3. $0.05 \mathrm{DEP}$ & 63.1 & +3.8 & 4.0 & -0.4 & 3.0 & -0.2 & 8.4 & -2.0 \\
\hline 4. 0.1 DEP & 57.5 & -1.8 & 4.8 & +0.4 & 3.1 & -0.1 & 9.4 & -1.0 \\
\hline 5. 0.02 DMS & 57.7 & -2.6 & 3.8 & -0.6 & 3.0 & -0.2 & 7.7 & -2.7 \\
\hline 6. 0.04 DMS & 57.7 & -2.6 & 6.6 & +2.2 & 3.1 & -0.1 & 7.7 & -2.7 \\
\hline 7. $0.08 \mathrm{DMS}$ & 60.0 & +0.7 & 4.3 & -0.1 & 3.0 & -0.2 & 8.2 & -2.2 \\
\hline$x$ & 59.5 & & & & 3.0 & & & \\
\hline$S \bar{x}$ & \pm 1.3 & & & & \pm 0.1 & & & \\
\hline $\mathrm{V} \pm \mathrm{S}_{\mathrm{v}}$ & & & $4.8 \pm 1.7$ & & & & $8.6 \pm 1.4$ & \\
\hline
\end{tabular}

In relation to the control and the total average, the greatest decrease in leaf width was noted at low and medium concentrations of $0.02 \ldots 0.05 \%$ DEP and at low and high concentrations of 0.02 and $0.08 \%$ DMS. Variability of leaf width ranged from minimum to maximum $(\mathrm{V}=5.1 \ldots 10.4 \%)$.

In garlic breeding, important traits are the height and diameter of the bed stem. In our case, the concentration of the preparation $0.05 \%$ DEP by $16.1 \%$ increased its height with a decrease in the diameter of the bed stem by $9.1 \%$, which had a positive effect on the yield of garlic (table 4).

Table 4. Morphometric signs of the height of the bed stem and its diameter of Allium sativum L. (2017-2019).

\begin{tabular}{|c|c|c|c|c|c|c|c|c|}
\hline \multirow{2}{*}{$\begin{array}{l}\text { Number of } \\
\text { mutant and } \\
\text { concentration } \\
\text { of mutagen } \\
(\%)\end{array}$} & \multicolumn{4}{|c|}{$\begin{array}{l}\text { Height and variability of the bed } \\
\text { stem }\end{array}$} & \multicolumn{4}{|c|}{$\begin{array}{l}\text { Diameter and variability of the bed } \\
\text { stem }\end{array}$} \\
\hline & $\mathrm{cm}$ & \pm to st & $\mathrm{V}, \%$ & $\begin{array}{l} \pm \text { to } \\
\text { st, } \%\end{array}$ & $\mathrm{~cm}$ & $\begin{array}{c} \pm \text { to } \\
\text { st }\end{array}$ & $\mathrm{V}, \%$ & \pm to st $\%$ \\
\hline $\begin{array}{l}\text { 1. Control, } \\
\text { st (without } \\
\text { treatment) }\end{array}$ & 12.4 & 0.0 & 9.3 & 0.0 & 2.2 & 0.0 & 9.6 & 0.0 \\
\hline 2. $0.025 \mathrm{DEP}$ & 12.3 & -0.1 & 7.6 & -1.7 & 2.3 & +0.1 & 10.3 & +0.7 \\
\hline 3. $0.05 \mathrm{DEP}$ & 12.6 & +0.2 & 7.3 & -2.0 & 2.0 & -0.2 & 9.2 & -0.4 \\
\hline 4. 0.1 DEP & 12.4 & 0.0 & 7.2 & -2.1 & 2.2 & 0.0 & 10.4 & +0.8 \\
\hline 5. $0.02 \mathrm{DMS}$ & 11.3 & -1.1 & 7.3 & -2.0 & 2.5 & +0.3 & 6.6 & -3.0 \\
\hline 6. $0.04 \mathrm{DMS}$ & 11.8 & -0.6 & 6.3 & -3.0 & 2.2 & 0.0 & 8.4 & -1.2 \\
\hline 7. $0.08 \mathrm{DMS}$ & 12.2 & -0.2 & 11.8 & +2.5 & 2.5 & +0.3 & 9.1 & -0.5 \\
\hline$x$ & 12.1 & & & & 2.3 & & & \\
\hline$S \bar{x}$ & \pm 0.5 & & & & \pm 0.1 & & & \\
\hline $\mathrm{V} \pm \mathrm{S}_{\mathrm{v}}$ & & & $8.1 \pm 2.4$ & & & & $9.1 \pm 2.4$ & \\
\hline
\end{tabular}


With an increase in the concentration of the DMS preparation from the minimum to the maximum $(0.02 \ldots 0.08 \%)$, the height of the bed stem increased by $8 \%$. However, these indicators did not exceed the total average $\bar{x}=12.1 \mathrm{~cm}$ with an absolute error of the average $S \bar{x}=0.5$ and insignificant variability of the indicator $(\mathrm{V}=8.1 \%)$. With a lower bed stem height of 11.3 and $11.8 \mathrm{~cm}$ in relation to the control $12.4 \mathrm{~cm}$ at a preparation concentration of $0.02 \ldots 0.08 \mathrm{DMS}$, an increase in the yield of garlic was also achieved. Bed stem diameter affects the strength of the stem and the rate of bulb formation. Thus, at the concentrations of the minimum and maximum DMS (0.02 and 0.08\%), an increase in the diameter of the bed stem was noted by $9.1 \%$ compared to the control and the average total indicator $\bar{x}=2.3 \mathrm{~cm}$ with an absolute error of the average $S \bar{x} \pm 0.1$ and insignificant variability $(\mathrm{V}=9.1 \%)$; insignificant variability of the diameter of the bed stem $(\mathrm{V}=9.2 \%)$ was also noted after treatment with DEP at a concentration of $0.05 \%$.

The most important indicators of productivity are the diameter and weight of garlic bulbs (table 5). The treatment of garlic air bulbs with mutagens $0.05 \%$ DEP and $0.02 \%$ DMS increased the diameter of the bulbs by $12 \%$, where their size was $1.3 \mathrm{~cm}$ higher than the average total $\bar{x}=7.8 \mathrm{~cm}$ with an average error of $\bar{S} \bar{x} \pm 0.5$ and insignificant variability $(\mathrm{V}=9.7 \%)$.

Table 5. Morphometric characteristics of the diameter and weight of Allium sativum L. winter garlic bulbs (2017-2019).

\begin{tabular}{|c|c|c|c|c|c|c|c|c|}
\hline $\begin{array}{c}\text { Number of } \\
\text { mutant and } \\
\begin{array}{c}\text { concentration of } \\
\text { mutagen (\%) }\end{array}\end{array}$ & \multicolumn{3}{|c|}{ Bulb diameter and variability } & \multicolumn{4}{c|}{ Bulb weight and variability } \\
\cline { 2 - 10 } & $\mathrm{cm}$ & \pm to st & $\mathrm{V}, \%$ & $\begin{array}{c} \pm \text { to } \\
\text { st, } \%\end{array}$ & $\mathrm{~g}$ & $\begin{array}{c} \pm \text { to } \\
\text { st }\end{array}$ & $\mathrm{V}, \%$ & $\begin{array}{r} \pm \text { to } \\
\text { st, } \%\end{array}$ \\
\hline $\begin{array}{c}\text { 1. Control, } \\
\text { st (without } \\
\text { treatment) }\end{array}$ & 7.5 & 0.0 & 11.7 & 0.0 & 116.0 & 0.0 & 1.2 & 0.0 \\
\hline $2.0 .025 \mathrm{DEP}$ & 7.7 & +0.2 & 12.4 & +0.7 & 123.3 & +7.3 & 3.5 & +2.3 \\
\hline $3.0 .05 \mathrm{DEP}$ & 8.4 & +0.9 & 10.8 & -0.9 & 113.3 & -2.7 & 4.3 & +3.1 \\
\hline $4.0 .1 \mathrm{DEP}$ & 7.5 & 0.0 & 8.0 & -3.7 & 103.0 & -13.0 & 5.6 & +3.9 \\
\hline $5.0 .02 \mathrm{DMS}$ & 8.4 & +0.9 & 9.9 & -1.8 & 120.3 & +4.3 & 4.4 & +3.2 \\
\hline $6.0 .04 \mathrm{DMS}$ & 7.3 & -0.2 & 6.3 & -5.4 & 109.5 & -6.5 & 4.0 & +2.8 \\
\hline $7.0 .08 \mathrm{DMS}$ & 8.1 & +0.6 & 9.0 & -2.7 & 112.3 & -3.7 & 3.7 & +2.5 \\
\hline $\bar{X}$ & 7.8 & & & & 114.0 & & & \\
\hline $\bar{S}$ & \pm 0.5 & & & & \pm 8.0 & & & \\
\hline $\mathrm{V} \pm \mathrm{S}_{\mathrm{v}}$ & & & $9.7 \pm 1.7$ & & & & $3.8 \pm 0.8$ & \\
\hline
\end{tabular}

The yield value was also determined by the mass of the bulbs, the greatest value was shown by preparations with a minimum concentration of $0.025 \%$ DEP and $0.02 \%$ DMS $120.3 \ldots 23.3 \mathrm{~g}$ with a cumulative average $\bar{x}=114 \mathrm{~g}$ and an absolute error of average $S \bar{x}=$ $8.0 \mathrm{~g}$ and insignificant variability in the mass of bulbs $(\mathrm{V}=3.8 \%)$.

Thus, the treatment of air bulbs with mutagens $0.05 \%$ DEP and $0.02 \%$ DMS not only increased the morphometry indices of mutants (plant height, number of leaves), changed the height and diameter of the bed stem, but also increased the yield by $20.7 . .27 .9 \%$ in comparison with the control (table 6). For example, pre-sowing seed treatment with DMS also stimulated the growth and development of Calendula officinalis L. plants. They exceeded the control variants in biometric parameters, raw material and seed yields (Khazieva et al [21]). 
Table 6. Yield of winter garlic and its variability (2019-2020).

\begin{tabular}{|c|c|c|c|c|}
\hline $\begin{array}{c}\text { Mutant number and mutagen } \\
\text { concentration (\%) }\end{array}$ & $\begin{array}{c}2019 \\
\text { year }\end{array}$ & $\begin{array}{c}2020 \\
\text { year }\end{array}$ & $\begin{array}{c}\text { Average } \\
\text { for 2019- } \\
2020\end{array}$ & $\begin{array}{c}\text { Variability } \\
(\mathrm{V}, \%)\end{array}$ \\
\hline $\begin{array}{c}\text { 1. Control, st (without } \\
\text { treatment) }\end{array}$ & $1.32 \pm 0.1$ & $1.77 \pm 0.1$ & $1.54 \pm 0.1$ & 7.9 \\
\hline 2. 0.025 DEP & $1.49 \pm 0.0$ & $1.73 \pm 0.2$ & $1.61 \pm 0.1$ & 3.7 \\
\hline 3. 0.05 DEP & $1.56 \pm 0.0$ & $2.38 \pm 0.2$ & $1.97 \pm 0.1$ & 7.2 \\
\hline 4.0.1 DEP & $1.12 \pm 0.0$ & $1.82 \pm 0.1$ & $1.47 \pm 0.1$ & 4.8 \\
\hline $5.0 .02 \mathrm{DMS}$ & $1.54 \pm 0.1$ & $2.17 \pm 0.2$ & $1.86 \pm 0.1$ & 3.7 \\
\hline $6.0 .04 \mathrm{DMS}$ & $1.59 \pm 0.0$ & $2.00 \pm 0.2$ & $1.80 \pm 0.1$ & 7.9 \\
\hline $7.0 .08 \mathrm{DMS}$ & $1.36 \pm 0.0$ & $1.58 \pm 0.1$ & $1.47 \pm 0.0$ & 4.3 \\
\hline $\bar{x} \pm \mathrm{S} \bar{x}$ & & & & \\
\hline & $1.43 \pm 0.1$ & $1.92 \pm 0.2$ & $1.67 \pm 0.08$ & $5.64 \pm 1.73$ \\
\hline
\end{tabular}

An increase in yield by $16.9 \%$ was also noted when processing air bulbs with $0.04 \%$ DMS. The variants with the treatment of air bulbs with $0.05 \%$ DEP and $0.02 \ldots 0.04 \%$ DMS significantly exceeded the average yield values $\left(1.67 \mathrm{~kg} / \mathrm{m}^{2}\right)$ by $1.1 \ldots 1.2$ times. Coefficients of variation for yield were in the range of $3.7 \ldots 7.9 \%$ with insignificant average variability $\mathrm{V}=5.64 \pm 1.73 \%$. Evaluation of the chemical composition of products using mutagens is a significant indicator in the selection of winter garlic. In comparison with the control, an increase in the concentrations of DEP and DMS to the maximum led to an increase in the dry matter content for the preparations by 7.6 and $8.1 \%$. The highest dry matter content in garlic was noted when using $0.1 \%$ DEP $-44.0 \%$ and $0.08 \%$ DMS $-44.2 \%$, where the excess of the average value $(\bar{x}=42.6 \%$ ) by $3.3 \ldots 3.8 \%$ is reliably shown (table 7 ).

Table 7. Chemical composition of garlic when using mutagens.

\begin{tabular}{|c|c|c|c|c|}
\hline $\begin{array}{c}\text { Mutant number } \\
\text { and mutagen } \\
\text { concentration (\%) }\end{array}$ & Dry matter, \% & $\begin{array}{c}\text { Content of total } \\
\text { sugars, \% }\end{array}$ & $\begin{array}{c}\text { Content of } \\
\text { vitamin C, } \\
\mathrm{mg} / 100 \mathrm{~g}\end{array}$ & $\begin{array}{c}\text { Mass fraction } \\
\text { of essential } \\
\text { oil, } \%\end{array}$ \\
\hline $\begin{array}{c}\text { 1. Control, st } \\
\text { (without treatment) }\end{array}$ & $40.9 \pm 0.4$ & $10.70 \pm 0.36$ & $5.17 \pm 0.29$ & $0.045 \pm 0.001$ \\
\hline 2. 0.025 DEP & $42.1 \pm 0.3$ & $10.53 \pm 0.09$ & $3.70 \pm 0.02$ & $0.032 \pm 0.002$ \\
\hline 3. 0.05 DEP & $39.5 \pm 0.2$ & $11.83 \pm 0.01$ & $3.20 \pm 0.02$ & $0.093 \pm 0.004$ \\
\hline 4.0 .1 DEP & $44.0 \pm 0.1$ & $12.40 \pm 0.09$ & $2.71 \pm 0.16$ & $0.038 \pm 0.001$ \\
\hline 5. 0.02 DMS & $43.8 \pm 0.3$ & $11.55 \pm 0.07$ & $4.45 \pm 0.17$ & $0.063 \pm 0.003$ \\
\hline 6.0 .04 DMS & $43.7 \pm 0.2$ & $11.62 \pm 0.13$ & $5.02 \pm 0.05$ & $0.126 \pm 0.010$ \\
\hline 7.0 .08 DMS & $44.2 \pm 0.1$ & $11.26 \pm 0.01$ & $3.46 \pm 0.16$ & $0.017 \pm 0.004$ \\
\hline $\bar{x}$ & $42.6 \pm 0.2$ & $11.40 \pm 0.11$ & $3.90 \pm 0.12$ & $0.048 \pm 0.003$ \\
\hline
\end{tabular}

In comparison with the control, an increase in the concentration of mutagens also contributed to the accumulation of total sugars for both drugs. At $0.1 \%$ DEP, the accumulation of sugars reached $12.4 \%$, which is $15.9 \%$ more than the control; at the lowest and average concentration of DMS 0.02 and DMS 0.04\%, an increase in the content of total sugars with an excess of control by $7.9 \ldots 8.6 \%$ was also noted with an excess of the average value $\bar{x}=11.4$ for DEP by $8.6 \%$ and DMS by $1.8 \%$.

It was found that strong correlations in garlic $\mathrm{r}=0.83$ and 0.97 - "leaf length - bulb weight" were noted in mutants No. 5 and 7 and also in "leaf length - bulb diameter" at $r=$ 0.70 and 0.99 in variants No. 2, 4 and 7. The rest of the mutants were noted at low and 
medium values of $\mathrm{r}=0.2 \ldots 0.63$. Evaluation of the vitamin $\mathrm{C}$ content showed that different concentrations did not have a significant effect on the increase in vitamin $\mathrm{C}$ in production. The greatest accumulation of essential oil was observed in the average preparation concentrations of $0.05 \%$ DEP and $0.04 \%$ DMS, which is 2.1 and 2.8 times more than the control, with a significant excess of the average value $\bar{x}=0.048 \%$ by 1.9 and 2.6 times.

\section{Conclusion}

Thus, the treatment of air bulbs with mutagens $0.05 \%$ DEP and $0.02 \%$ DMS not only increased the morphometric parameters of mutants (plant height, number of leaves), changed the height and diameter of the bed stem, but also increased the yield of garlic by $20.7 . .27 .9 \%$ compared to the control. Mutants with low variability of economically valuable traits, morphometry and increased content of total sugars and essential oil (No. 3, $5,6)$ are recommended for use for breeding purposes.

\section{References}

1. Sych Z D 2013 Vegetable growing 10 Kiev 15-17

2. Polyakov A V and Zubaliy A V 2015 The scientific support for the vegetable industry of Russia in modern conditions (Moscow) pp 328-332

3. IAEA (International Atomic Energy Agency) 1991 Plant mutation breeding for crop improvement Proc. of an Int. Symp. on the contribution of plant mutation breeding to crop improvement vol 1 (Vienna)

4. Nemtinov V I and Shirokova A V 2019 Bulletin of GNBS 133 Yalta 187-194 DOI: 10.36305/0513-1634-2019-133-187-194

5. Zheng S, Kamenetsky R, Fereol L, Barandiaran X and Rabinowitch D 2007 Med. Aromatic Plant Sci. Biotechn. 1(1) 6-15

6. Matijevic M, Bado S, Lagoda P and Foster B 2013 Plant Genetics and Breeding Technologies (Vienna: Monduzci) pp 45-47

7. IAEA (International Atomic Energy Agency) 2005 Gamma irradiations for radiation processing Vienna 40

8. Taner Y and Kunter B 2004 Bahçe 33 95-99

9. Hazieva F M, Basalaeva I V, Tockaja S A et al 2014 Voprosy biologicheskoj, medicinskoj i farmacevticheskoj himii 46

10. Piri I, Babayan M, Tavassoli A and Javahen M 2011 Afr. J. Microb. Res. 5(32) 5806-5811

11. Perez M, Aveldaño M and Croci M 2007 Postharv. Biol. Techn. 44(2) 122-130

12. Wi S, Chung B, Kim J Kim J Baek M and Lee J 2007 Micron. 38(6) 553-564

13. Ilyina Z 2012 Int. Conf. Food Industry of Belarus: marketing, logistics, innovations Minsk 1-5

14. Koretsky V V and Kupreenko N P 2015 RUP "Institute of Vegetable Growing of Belarus" Minsk 82-87

15. Litvinov S S and Borisov V A 2015 The scientific support for the vegetable industry of Russia in modern conditions Collection of scientific papers of All-Russian Research Institute of Vegetable Growing Moscow 16-23

16. Kakareka N N and Pleshakova T I 2013 Potato and Vegetables 6 Moscow 13-14 
17. Nalobova V L, Kuprienko N P, Moitekhovich V I and Koretsky V V 2013 RUP "Collection of scientific works of the Institute of Vegetable growing" 21 Minsk 142-147

18. El-Nashar Y I and Asrar A A 2016 Genetics and Molecular Research 15 (2) 1-14

19. Roychowdhuri R and Tah J 2011 Current Botany 2(8) 19-23

20. Kudina G A 2006 Industrial botany 6 116-120

21. Khazieva F M, Svistunova N Yu and Samatadze T E 2016 Questions of biological, medical and pharmaceutical chemistry $837-42$ 